\title{
Porungo cheese whey: $\beta$-galactosidase production, characterization and lactose hydrolysis
}

\section{Soro de queijo porungo: produção de $\beta$-galactosidase, caracterização e hidrólise da lactose}

\author{
Aline Vitória Corim Marim¹, Sabrina Gabardo ${ }^{1 *}$ (D), Marco Antônio Záchia Ayub² \\ ${ }^{1}$ Universidade Federal de São Carlos (UFSCar), Centro de Ciências Agrárias, Departamento de Tecnologia \\ Agroindustrial e Socioeconomia Rural, Araras/SP - Brasil \\ ${ }^{2}$ Universidade Federal do Rio Grande do Sul (UFRGS), Instituto de Ciência e Tecnologia dos Alimentos, \\ Laboratório de Biotecnologia e Engenharia Bioquímica (BiotecLab), Porto Alegre/RS - Brasil
}

${ }^{*}$ Corresponding Author: Sabrina Gabardo, Universidade Federal de São Carlos (UFSCar), Centro de Ciências Agrárias, Departamento de Tecnologia Agroindustrial e Socioeconomia Rural, Rodovia Anhanguera, km 174 CEP: 13600-970, Araras/SP - Brasil, e-mail: sabrinagabardo@ufscar.br

Cite as: Marim, A. V. C., Gabardo, S., \& Ayub, M. A. Z. (2021). Porungo cheese whey: $\beta$-galactosidase production, characterization and lactose hydrolysis. Brazilian Journal of Food Technology, 24, e2021038. https://doi.org/10.1590/1981-6723.03821

\begin{abstract}
This study evaluated the lactose hydrolysis by immobilized $\beta$-galactosidase, which was produced by Kluyveromyces marxianus using porungo cheese whey as substrate. Initially, the yeast was cultivated in porungo cheese medium at $30{ }^{\circ} \mathrm{C}$ and $200 \mathrm{rpm}$, showing a maximal $\beta$-galactosidase production of $14.19 \mathrm{U} \mathrm{mL}^{-1}$. The crude extract obtained was used to evaluate the enzymatic hydrolysis in lactose solution. The optimal $\mathrm{pH}$ and temperature of the free and immobilized enzyme was investigated, whereas the lactose hydrolysis was carried out using two enzyme solutions (total activities of $2 \mathrm{U}$ and $6 \mathrm{U}$ ) for both forms of the biocatalyst. Ca-alginate immobilization of $\beta$-galactosidase increased optimal temperature range to $40^{\circ} \mathrm{C}$, compared to the value for the free enzyme, which was $37^{\circ} \mathrm{C}$. The optimal $\mathrm{pH}$ was also increased by immobilization to 7.0 , from $\mathrm{pH} 6.5$ observed for the free enzyme. The highest lactose hydrolysis conversion was $15.82 \%$ using $6 \mathrm{U}$ of free enzyme and $13.77 \%$ for $2 \mathrm{U}$ of immobilized enzyme. Although, free enzyme showed higher conversion rates in the initial reaction time, the immobilized enzyme kept operational stability throughout reaction time, suggesting the advantage of using this technology. The use of porungo cheese whey allowed to aggregate value to this agro-industrial by-product, with the concomitant production of $\beta$-galactosidase to be used in the food industry chain itself.
\end{abstract}

Keywords: Agro-industrial residue; $\beta$-galactosidase; Enzymatic hydrolysis; Enzyme immobilization; Lactose; Whey.

\section{Resumo}

Este trabalho analisou a hidrólise da lactose por $\beta$-galactosidase imobilizada, produzida por Kluyveromyces marxianus, utilizando soro de queijo porungo como substrato. Inicialmente, a levedura foi cultivada em meio soro de queijo porungo, nas condições de $30^{\circ} \mathrm{C}$ e $200 \mathrm{rpm}$, apresentando produção máxima de $\beta$-galactosidase de 14,19 
$\mathrm{U} \mathrm{mL}^{-1}$. O extrato bruto obtido foi utilizado para avaliar a hidrólise enzimática em solução de lactose. O pH e a temperatura ótimos da enzima livre e imobilizada foram investigados, e a hidrólise da lactose foi realizada utilizando duas soluções enzimáticas (atividades totais de 2 U e $6 \mathrm{U}$ ) para ambas as formas do biocatalisador. A imobilização de $\beta$-galactosidase com alginato de cálcio aumentou a faixa de temperatura ótima para $40^{\circ} \mathrm{C}$, em comparação com a faixa de temperatura ótima da enzima livre, que foi de $37^{\circ} \mathrm{C}$. O pH ótimo também foi aumentado com o uso da imobilização quando comparado ao $\mathrm{pH}$ ótimo da enzima livre, alcançando $\mathrm{pH} 7,0$ frente ao $\mathrm{pH} 6,5$ observado para a enzima livre. A maior conversão de hidrólise de lactose foi de 15,82\% usando 6 U de enzima livre e 13,77\% para $2 \mathrm{U}$ de enzima imobilizada. Embora a enzima livre tenha apresentado maiores taxas de conversão no tempo inicial de reação, a enzima imobilizada manteve estabilidade operacional ao longo do tempo de reação, sugerindo a vantagem do uso desta tecnologia. O uso do soro de queijo porungo permite agregar valor a esse subproduto agroindustrial com a concomitante produção de $\beta$-galactosidase para uso na própria cadeia da indústria alimentícia.

Palavras-chave: Resíduos agroindustriais; $\beta$-galactosidase; Hidrólise enzimática; Imobilização enzimática; Lactose; Soro de queijo.

\section{Introduction}

The use of agro-industrial by-products or residues, such as cheese whey, as cheap and alternative substrates in biotechnological processes have been widely researched to obtain added-values biomolecules and has encouraged development of new strategies in bioprocess technology (Christensen et al., 2011; Gabardo et al., 2016). Cheese whey is the main residue of the dairy industry, presenting some problems for its discharge because of its high organic load and the high amount of it that is daily produced worldwide. The global production of whey was estimated at around 200 million tons per year, with an annual growth rate of 1.64 (Fischer \& Kleinschmidt, 2015; Das et al., 2016; Domingos et al., 2018). Whey has a Biological Oxygen Demand (BOD) ranging from $30 \mathrm{~g} \mathrm{~L}^{-1}$ to $50 \mathrm{~g} \mathrm{~L}^{-1}$, with an estimated $50 \%$ of this amount being disposed of in wastewater treatment plants or used as raw feeding in farms (Siso, 1996; Guimarães et al., 2010; Gabardo et al., 2014; Das et al., 2016). Due to its nutrient composition, rich in lactose (45-50 $\left.\mathrm{g} \mathrm{L}^{-1}\right)$, protein $\left(6-8 \mathrm{~g} \mathrm{~L}^{-1}\right)$, lipids $\left(4-5 \mathrm{~g} \mathrm{~L}^{-1}\right)$, and mineral salts $\left(5-7 \mathrm{~g} \mathrm{~L}^{-1}\right)$, the remaining volume of the cheese whey have a potential to be applied in bioprocess as substrate for microbial growth to obtain several biomolecules, especially enzymes such as $\beta$-galactosidase, serving as alternative carbon low-cost to production of food industry (Siso, 1996; Guimarães et al., 2010; Prazeres et al., 2012; Domingos et al., 2018; Coelho et al., 2021; Bolognesi et al., 2021).

Porungo cheese is manufactured by farmers using raw milk and has similar characteristics of mozzarella cheese, being produced in the southwestern region of São Paulo State, in Brazil. It naturally contains a large number of lactic bacteria prevenient from fermented whey of the previous cheese production (Pezzo, 2017; Coelho et al., 2021; Bolognesi et al., 2021). Until now, our research groups are a pioneer group to investigate the biotransformation of porungo cheese whey in bioprocess.

The enzyme $\beta$-galactosidase is produced in bioprocess using yeasts such as Kluyveromyces lactis, K. fragilis, K. marxianus (Grosová et al., 2008; Pereira et al., 2012; Fai \& Pastore, 2015; Falleiros, 2016). This enzyme is widely used by the food industry to obtain low-lactose products by the enzymatic hydrolysis of lactose. The use of $\beta$-galactosidase is the most important biotechnological process used in the food industry, which offers benefits in areas such as health and food technology (Grosová et al., 2008; Rosenberg, 2006; Husain, 2010; DavaniDavari et al., 2019; Bolognesi et al., 2021). Considering that approximately $75 \%$ of world adult population suffers from some limitation concerning milk consumption and other dairy products, technologies that can improve the quality of life should be valued, in which lactose hydrolysis is one way to remedy this situation. Further technologies of enzyme immobilization can improve on several advantages in this process (Grosová et al., 2008; Husain, 2010; Klein et al., 2013).

The main advantage of enzyme immobilization is the reuse of the immobilized biocatalyst, reducing costs associated with the process. Among the main advantages of the technique are the improvement in operational 
and thermal stability, recovery and reuse of the enzyme, ease in separating enzyme from reaction medium, and reduction of contamination of the final product (Krajewska, 2004; Panesar et al., 2010; Sheldon \& Van Pelt, 2013). The use of low-cost supports, such as alginate, is an interesting alternative for industrial use of immobilized enzymes because this support allows high enzymatic retention, resistance to changes in $\mathrm{pH}$ and temperature (Amsden \& Turner, 1999; Serp et al., 2000; Bolognesi et al., 2021).

Regarding these considerations, this study aimed to investigate the lactose enzymatic hydrolysis by $\beta$ - galactosidase produced in porungo cheese whey medium in fermentations of $K$. marxianus. Free and immobilized enzymes were tested, and the optimal $\mathrm{pH}$ and temperature of the enzyme were also investigated.

\section{Materials and methods}

\subsection{Porungo cheese whey}

The porungo cheese whey was provided by farmers located in the southwest of the State of São Paulo, in Brazil (geocoordinates $23^{\circ} 29^{\prime} 04.2^{\prime \prime} \mathrm{S}$ and $48^{\circ} 20^{\prime} 14.7^{\prime \prime} \mathrm{W}$ ). This material was stored frozen in a freezer at $-16^{\circ} \mathrm{C}$.

\subsection{Microorganisms}

Kluyveromyces marxianus CCT 4086 was donated by Biotechnology and Biochemical Engineering Laboratory of the Food Science and Technology Institute of the Federal University of Rio Grande do Sul, in Brazil. The yeast cells were kept at $4{ }^{\circ} \mathrm{C}$ in YEP-Lactose medium, composed of yeast extract $\left(10 \mathrm{~g} \mathrm{~L}^{-1}\right)$, bacteriological peptone $\left(20 \mathrm{~g} \mathrm{~L}^{-1}\right)$, lactose $\left(20 \mathrm{~g} \mathrm{~L}^{-1}\right)$ and agar $\left(20 \mathrm{~g} \mathrm{~L}^{-1}\right)$.

\section{$2.3 \beta$-galactosidase production}

The enzyme was produced in a medium containing porungo cheese whey supplemented with $3 \mathrm{~g} \mathrm{~L}^{-1}$ of yeast extract. The porungo cheese whey used in this work was composed of water $(93.25 \%)$, lactose $(4.30 \%)$, proteins $(1.09 \%)$, lipids $(0.30 \%)$, dry extract $(6.76 \%)$ and ashes $(0.53 \%)$, analyzed by our research group (Coelho et al., 2021$)$. The culture conditions followed procedures according to a previous work of our group (Coelho et al., 2021). To avoid precipitation during autoclaving, whey proteins were hydrolyzed using a commercial protease (Alcalase $2.4 \mathrm{~L}$, 2.4 UA-A g ${ }^{-1}$, Tovani Benzaquen Ingredients, São Paulo, Brazil) at $\mathrm{pH} 8.5,55^{\circ} \mathrm{C}$ for $3 \mathrm{~h}$. Inocula was prepared by transferring one isolated yeast colony to $250 \mathrm{~mL}$ Erlenmeyers containing $50 \mathrm{~mL}$ of YEP-lactose medium and incubated in an orbital shaker at $200 \mathrm{rpm}$ for $15 \mathrm{~h}$ and at $30^{\circ} \mathrm{C}$. Cell concentration was standardized for optical density at $600 \mathrm{~nm}$ (DO 600nm) equal 1.0. The enzyme production was carried out in $250 \mathrm{~mL}$ Erlenmeyers, containing $45 \mathrm{~mL}$ of sterilized cultivation media $\left(121^{\circ} \mathrm{C}\right.$ for $\left.15 \mathrm{~min}\right)$ and $5 \mathrm{~mL}$ of inoculum, at $30{ }^{\circ} \mathrm{C}$ and $200 \mathrm{rpm}$. Samples were withdrawn periodically at each $5 \mathrm{~h}$ up to $25 \mathrm{~h}$ of cultivation to determine lactose concentration, biomass and enzymatic activity. All experiments were performed in duplicate.

\subsection{Analytical methods}

\subsubsection{Enzymatic extraction by mechanical cell disruption}

The enzyme was extracted using glass pearls and a vortex mixer. The culture medium was centrifuged at $3,000 \times \mathrm{g}$ for $15 \mathrm{~min}$ and the cell pellet resuspended in $0.1 \mathrm{M}$ of phosphate buffer ( $\mathrm{pH}$ 7.3) using $1.1 \mathrm{~g}$ of glass pearls for each $\mathrm{mL}$ of cell suspension (Medeiros et al., 2008), agitated in a vortex for eight (8) cycles of $5 \mathrm{~min}$. The disrupted cell suspension was centrifuged $(3,000 \times \mathrm{g}, 15 \mathrm{~min})$ and the enzyme extract was used to determine enzyme activity. 


\subsubsection{Biomass and lactose concentration}

Cell concentration was determined using calibration curve correlating optical density at $600 \mathrm{~nm}$ with dry cell weight ( $\mathrm{g} \mathrm{L}^{-1}$ ) (Gabardo et al., 2014). Lactose concentration was determined by the 3,5-dinitrosalicylic acid (DNS) method (Miller, 1959) in spectrophotometer at $540 \mathrm{~nm}$ using lactose calibration curve as standard (linearity range of $0.5 \mathrm{~g} \mathrm{~L}^{-1}$ to $5.0 \mathrm{~g} \mathrm{~L}^{-1}, \mathrm{R}^{2}=0.9948$ ).

\subsubsection{Enzymatic activity}

Enzymatic activity of $\beta$-galactosidase was determined using o-nitrophenyl- $\beta$-D-galactopyranoside (ONPG) as a substrate (Klein et al., 2013). The reaction was carried out by mixing $50 \mu \mathrm{L}$ of crude enzymatic extract and $0.5 \mathrm{~mL}$ of activity buffer composed of $0.1 \mathrm{M}$ of potassium phosphate buffer ( $\mathrm{pH} 7.0$ ), containing $1.5 \mathrm{mM}$ of magnesium chloride $\left(\mathrm{MgCl}_{2}\right)$ (activity buffer) and $10 \mathrm{mM}$ of ONPG for $2 \mathrm{~min}$ at $37{ }^{\circ} \mathrm{C}$. The reaction was stopped by the addition of $0.1 \mathrm{M}$ of sodium carbonate buffer $(\mathrm{pH} 10.0)$. The o-nitrophenol (ONP) released was determined using spectrophotometer at $415 \mathrm{~nm}$. One unit of enzymatic activity (U) was defined as the amount of enzyme needed to release $1 \mu \mathrm{mol}$ of ONP per minute under analysis conditions.

\subsection{4 $\beta$-galactosidase immobilization}

The $\beta$-galactosidase immobilization was carried out in calcium alginate (Ca-alginate) beads. The enzymatic extract was dissolved in activity buffer to obtain either $2 \mathrm{U}$ or $6 \mathrm{U}$ in the total volume of $10 \mathrm{~mL}$, and this were added in a solution a solution containing $5 \%$ of sodium alginate, previously dissolved in potassium phosphate buffer $(0.1 \mathrm{M}$ and $\mathrm{pH} 7.0)$ and containing $1.5 \mathrm{mM}$ of magnesium chloride $\left(\mathrm{MgCl}_{2}\right)$. This mixture was dripped through peristaltic pump into a flask containing $0.05 \mathrm{M}$ of calcium chloride solution $\left(\mathrm{CaCl}_{2}\right)$ using a needle-coupled syringe $(6 \times 0.25 \mathrm{~mm})$. Afterward, the formed beads (diameter of $3.0 \pm 0.5 \mathrm{~mm}$ ) were gently agitated for $30 \mathrm{~min}$ and kept in contact with this solution for $1 \mathrm{~h}$, at $4{ }^{\circ} \mathrm{C}$ to stabilize the system. The activity of immobilized enzyme was determined as described above using a total of seven (7) beads as equivalent volume of $50 \mu \mathrm{L}$ used in the reaction.

\subsection{Optimal pH and temperature for free and immobilized $\beta$-galactosidase}

The influence of temperature on enzymatic activity of free and immobilized $\beta$-galactosidase was determined by varying temperature between $20^{\circ} \mathrm{C}$ and $60^{\circ} \mathrm{C}$, in an activity buffer at $\mathrm{pH} 7.0$. The influence of $\mathrm{pH}$ of activity of free and immobilized $\beta$-galactosidase was determined using activity buffer at $37{ }^{\circ} \mathrm{C}$, in a $\mathrm{pH}$ ranging from 5.5 to 8.0. The residual enzymatic activity was determined according to methodology described above. The tests were performed in triplicate.

\subsection{Lactose hydrolysis}

Enzymatic hydrolysis of lactose was carried out using free and immobilized extract of $\beta$-galactosidase using enzyme ( $2 \mathrm{U}$ or $6 \mathrm{U}$ ) in lactose solution $\left(50 \mathrm{~g} \mathrm{~L}^{-1}\right)$ prepared in activity buffer. The enzymatic hydrolysis of lactose processes was performed in a batch system using conical flasks incubated in an agitated water bath (50 rpm) at $37{ }^{\circ} \mathrm{C}$ and $\mathrm{pH}$ 6.5. Samples were withdrawn at different times and placed in ice bath to stop reaction instantaneously. Subsequently, glucose concentration was measured by the oxidase-peroxidase colorimetric method, using enzyme kit for glucose determination (Labtest, Minas Gerais, Brazil) in a spectrophotometer at $505 \mathrm{~nm}$. The conversion rate of lactose present in whey from porungo cheese was calculated according to Equation 1:

Conversion rate of lactose $(\%)=\frac{C_{g l u} \times M M_{l a c}}{C_{i_{l a c}} \times M M_{g l u}} \times 100$

where $\mathrm{C}_{\mathrm{glu}}$ is related to the glucose concentration, $\mathrm{MM}_{\mathrm{lac}}$ is the molar mass of lactose, $\mathrm{Ci}_{\text {lac }}$ is the initial lactose concentration and $\mathrm{MM}_{\mathrm{glu}}$ is the molar mass of glucose. 


\section{Results and discussion}

\subsection{Kinetics of enzyme production}

The kinetics of lactose consumption, biomass production and enzymatic activity are shown in Figure 1. The lactose was practically exhausted from medium at $20 \mathrm{~h}$ of cultivation, with a total of $85 \%$ consumed ( $\left.7.69 \mathrm{~g} \mathrm{~L}^{-1}\right)$, whereas maximum $\beta$-galactosidase activity was measured at $15 \mathrm{~h}$, reaching $14.19 \mathrm{U} \mathrm{mL}^{-1}$. These values were similar with those reported by Coelho et. al. (2021), who found the maximum $\beta$-galactosidase activity of $17.53 \mathrm{U} \mathrm{mL}^{-1}$ in $20 \mathrm{~h}$ of cultivation using the same strain of $K$. marxianus under the same conditions. Santiago et al. (2004) studied the $\beta$-galactosidase synthesis from K. marxianus ATCC 46537 using cheese whey with or without supplementation with yeast extract (at $30^{\circ} \mathrm{C}, 150 \mathrm{rpm}, \mathrm{pH} 5.5$ ) and observed a maximum of enzymatic activity of $20.00 \mathrm{U} \mathrm{mL}^{-1}$ and $12.00 \mathrm{U} \mathrm{mL}^{-1}$, respectively. The results were in agreement with findings reported by Rech et al. (1999) who studied the $\beta$-galactosidase production by two strains of K. marxianus, CBS 712 and CBS $6556\left(\right.$ at $30^{\circ} \mathrm{C}, 200 \mathrm{rpm}$ and $\mathrm{pH}$ 5.5), reporting maxima enzymatic activities of $5 \mathrm{U} \mathrm{mL}^{-1}$ for CBS 712 and approximately $10 \mathrm{U} \mathrm{mL}^{-1}$ for CBS 6556. The CBS 6556 strain grew in fresh cheese whey, while the CBS 712 strain required cheese whey supplemented with yeast extract. Braga et al. (2012) investigated the influence of supplementation of cheese whey with yeast extract, reaching $10.45 \mathrm{U} \mathrm{mL}^{-1}$ of maximum enzymatic activity. As explained above, the need for supplementation of cheese whey for $\beta$-galactosidase production was similarly reported by several researchers.

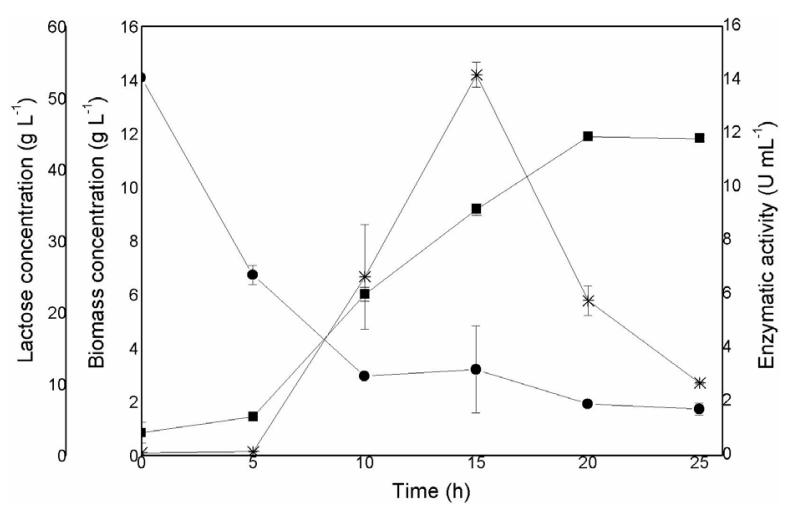

Figure 1. Kinetics of Kluyveromyces marxianus CCT 4086 growing in porungo cheese whey supplemented with yeast extract

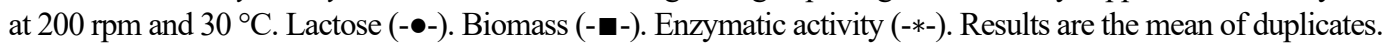

In fact, $\beta$-galactosidase is an intracellular enzyme, and cell disruption is essential to its extraction. Although mechanical methods are not specific, they have high efficiency and wide application compared to other methods of extraction, there is no need to remove contaminants otherwise present if chemical methods are used. Therefore, $\beta$ galactosidase can be directly applied in food (Numanoğlu \& Sungur, 2004; Medeiros et al., 2008).

\subsection{Optimal temperature and $\mathrm{pH}$ of free and immobilized $\beta$-galactosidase}

The activity of free and immobilized $\beta$-galactosidase was determined at temperatures ranging from $20{ }^{\circ} \mathrm{C}$ to $60{ }^{\circ} \mathrm{C}$ and at $\mathrm{pH}$ values ranging from 5.5 to 8.0. The effect of $\mathrm{pH}$ and temperature on the relative activity of the free and immobilized $\beta$-galactosidase are represented in Figure 2. Free and immobilized enzyme showed maximum enzymatic activity at $37^{\circ} \mathrm{C}$ (Figure 2a). Immobilization increased range of enzyme activity when compared to free enzyme, showing higher values of relative activity for temperatures between $40^{\circ} \mathrm{C}$ and $60{ }^{\circ} \mathrm{C}(12 \%$ to $20 \%)$. This is probably a consequence of the increased protective effect provided by immobilization support, which allows reduction of enzymatic inactivation and operational stability (Grosová et al., 2008; Panesar et al., 2010). Under the temperature of $45^{\circ} \mathrm{C}$ the residual activity of immobilized enzyme was $84.1 \%$, whereas for the free enzyme it was 
$67.5 \%$. In addition, enzymatic immobilization allowed reduction of contamination of the final product, the recovery of the biocatalyst and its reuse in further cycles of reaction (Krajewska, 2004; Grosová et al., 2008; Panesar et al., 2010). These results are in agreement with reports by Klein et al. (2013), who also observed an increase in the enzyme activity for $\beta$-galactosidase immobilized on glutaraldehyde-activated chitosan compared with free enzyme, for all temperatures tested $\left(10^{\circ} \mathrm{C}\right.$ to $\left.70^{\circ} \mathrm{C}\right)$. At $50^{\circ} \mathrm{C}$ the relative enzymatic active was around $90 \%$ whereas for free enzyme was around 78\%. A similar behavior was verified by Alves (2008) using immobilized $\beta$-galactosidase from K. marxianus CCT 7082 immobilized in calcium alginate, that observed the highest enzymatic activity at $37{ }^{\circ} \mathrm{C}$ and its decrease for temperatures above this. At $45^{\circ} \mathrm{C}$, the relative enzyme activity for immobilized enzyme was $83 \%$, whereas for free enzyme it was $67 \%$. Song et al. (2010) found $37{ }^{\circ} \mathrm{C}$ as optimal temperature of enzymatic activity, when testing different temperatures $\left(17-42{ }^{\circ} \mathrm{C}\right)$, using $\beta$-galactosidase of $K$. fragilis immobilized on silicagluteraldehyde. At $42{ }^{\circ} \mathrm{C}$, the relative enzymatic activity for immobilized enzyme was around $86 \%$, whereas for free enzyme it was around $61 \%$. In this work, both free and immobilized enzymes showed decreased enzymatic activity above $40{ }^{\circ} \mathrm{C}$, since $\beta$-galactosidase of yeasts are unstable above this temperature (Illanes et al.,1998), and are generally more thermo labile than those of the filamentous fungi and bacteria $\left(50-60^{\circ} \mathrm{C}\right)$ (Freitas, 2017).
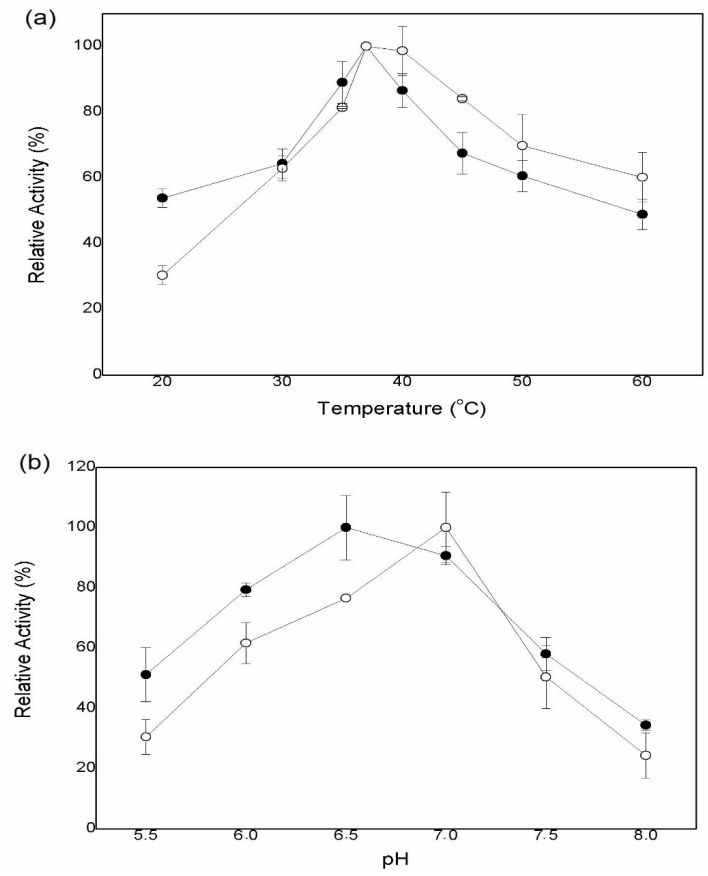

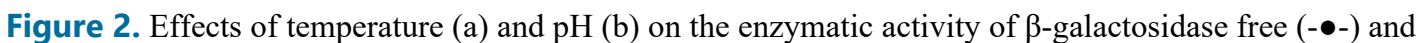
immobilized (-०-). Results are the mean of duplicates.

The effect of $\mathrm{pH}$ on enzymatic activity is shown in Figure $2 \mathrm{~b}$. The optima activities for free and immobilized $\beta$ - galactosidase were 6.5 and 7.0, respectively, shifting the optimum $\mathrm{pH}$ range of the immobilized biocatalyst, but not increasing its range in relation to the free form. This behavior can be explained by possible diffusion effects inside the beads containing the enzyme, which produces resistance to mass transfer in the support of immobilization. Despite several advantages of the immobilization in Ca-alginate systems, the main limitation of this technique is the diffusional barrier of substrates and products through the support. High enzyme density can difficult the contact between enzyme and substrate (Gabardo et al., 2011; Pilkington et al., 1998). The shift of the optimum $\mathrm{pH}$ of the enzyme from 6.6 to 7.7 after immobilization of $\beta$-galactosidase from $K$. lactis on graphite surfaces was reported by Zhou \& Chen (2001), which suggested that this is caused by enzymatic load of protein and graphite surfaces. Similarly, Song et al. (2010), after immobilizing $\beta$-galactosidase of $K$. lactis in chitosan macroparticles, reported increased optimum $\mathrm{pH}$ from 6.5 to a wider range between 6.5 and 8.0, suggesting a strong stabilizing effect in the enzyme. Jochems et al. (2011) tested $\beta$-galactosidase adsorbed in membranes containing zirconium dioxide and 
observed a change in the optimal $\mathrm{pH}$ from 6.5 to 7.0. The authors suggested that this was caused by the microenvironment around the membrane. The support can change the $\mathrm{pH}$ value in the surrounding environment of the enzyme catalytic site by changing the concentration of the charged species (Klein et al., 2013).

\subsection{Lactose hydrolysis}

The lactose hydrolysis rate into glucose and galactose by free and immobilized $\beta$-galactosidase produced from K. marxianus CCT 4086 is shown in Figure 3. The maxima conversion rates were $14.93 \%$ and $15.82 \%$ for enzyme solution of $2 \mathrm{U}$ and $6 \mathrm{U}$, respectively, after $210 \mathrm{~min}$ of reaction (Figure $3 \mathrm{a}$ ). The enzyme solution of $6 \mathrm{U}$ showed a kinetic slightly faster compared to $2 \mathrm{U}$, due to the higher amount of enzyme available to react with substrate. The lactose conversion was reduced over time of $900 \mathrm{~min}(15 \mathrm{~h})$ for both lactose solutions, owing to the lowest sugar remaining available to react. The better conversion rate was obtained using a lactose solution of $50 \mathrm{~g} \mathrm{~L}^{-1}$. Thus, the subsequent tests were carried out using this lactose concentration and the immobilized enzyme. The lactose conversion by $\beta$-galactosidase immobilized ( $2 \mathrm{U}$ and $6 \mathrm{U}$ ) (Figure $3 \mathrm{~b}$ ), showed the lower enzyme (2 U) producing higher values in conversion rate, reaching $13.77 \%$, in $1,440 \mathrm{~min}$ of the reaction, compared to $7.91 \%$ in $150 \mathrm{~min}$ for the immobilized enzyme. However, the main advantage was observed for immobilized enzyme solution of $2 \mathrm{U}$ because it allowed the operational stability, maintaining constant the conversion rate, whereas using $6 \mathrm{U}$ a decreased was verified, again possibly caused by more difficult mass transfer inside the particle (Gabardo et al., 2011; Pilkington et al., 1998). The conversion values would probably be higher if the enzyme was partially or totally purified, since the crude enzymatic extracts contain other similar proteins that can decrease the final volumetric activity as a consequence of surface competition of the support by other proteins. In addition, enzymes present in smaller amounts may have the opposite catalytic activity, decreasing the specificity of the biocatalyst (Barbosa et al., 2015; Fan et al., 2017). Although no inhibition tests were carried out, the conversion rate was probably not caused by inhibition of galactose. It is known that complete lactose hydrolysis is difficult to achieve due to inhibition by galactose and glucose in $\beta$-galactosidases, which can delay the hydrolysis process or even interrupt the reaction (Park \& Oh, 2010; Zhao et al., 2018; Zhang et al., 2018).
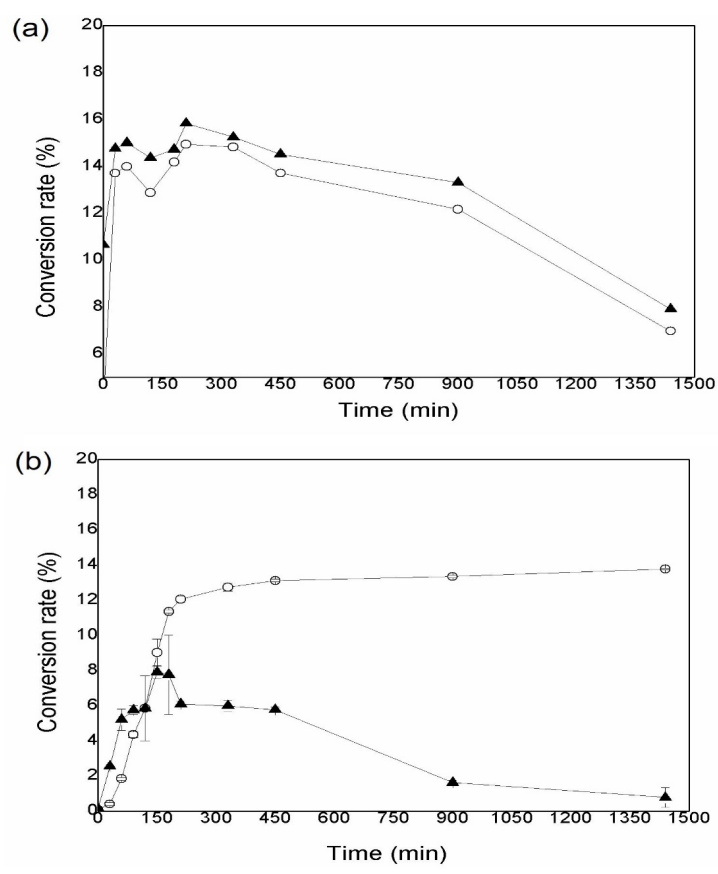

Figure 3. Conversion rate of lactose solution hydrolysis $\left(50 \mathrm{~g} \mathrm{~L}^{-1}\right)$ by (a) free and (b) immobilized $\beta$-galactosidase in solution of $2 \mathrm{U}(-\bullet-)$ and $6 \mathrm{U}\left(-\boldsymbol{\Delta}^{-}\right)$at $37^{\circ} \mathrm{C}$. Results are the mean of duplicates. 
Comparing the lactose hydrolysis by free and immobilized enzymes of $2 U$ (Figure 4), a faster initial lactose conversion rate into glucose was observed for the free enzyme, but afterwards the immobilized enzyme could reach values of conversion rate close to free form (after $450 \mathrm{~min}$ ), in contrast maintaining the conversion rate constant. The immobilized enzyme reached a conversion rate of $12.04 \%$ at $210 \mathrm{~min}$ of the reaction, whereas free $\beta$-galactosidase reached $14.93 \%$ at $210 \mathrm{~min}$. The slower kinetics at initial catalysis by immobilized enzyme can be explained due to the encapsulation inside Ca-alginate that may hinder the accessibility of the substrate to its active-site (Haider \& Husain, 2009). However, after $450 \mathrm{~min}$ the catalysis were similar for free (13.70\%) and immobilized (13.11\%) forms, indicating the operational stability provided by the immobilization technique. Similar results were described by Mörschbächer et al. (2016), who observed a conversion rate of $18 \%$ in 240 min for a commercial enzyme solution (525 U) (Lactozym $\left.{ }^{\circledR} 3000 \mathrm{~L}\right)$, which was much higher than the concentration in the present work. When the authors increased the immobilized enzyme solution to $1050 \mathrm{U}$, a high conversion rate was observed, thus reaching at 54\%. When testing glutaraldehyde, a crosslinking agent, the authors observed a decrease in conversion rate to $5 \%(525 \mathrm{U})$, a value of conversion lower than that observed in present study. This probably has been caused by the high reactivity of glutaraldehyde, that forms bonds between enzyme and immobilization support and may distort active site of the enzyme, leading to a loss of enzyme activity (Alonso et al., 2005; Betancor et al., 2006). In short, it can be observed in this research that lactose conversion rate varied from $1.62 \%$ to $15.82 \%$ for different variables such as lactose solution concentration, reaction time, enzyme concentration and free and immobilized enzyme, demonstrating that these variables influence the lactose hydrolysis process, but confirming that the immobilized enzyme provides operational stability for the system. Moreover, the results are promising for future studies concerning the application in foods because K. marxianus is recognized as a Generally Recognized as Safe (GRAS) by the Food and Drug Administration (FDA) (Rubio-Texeira, 2006; Lane et al., 2011), in addition to the characteristics of alginate being a non-toxic and inexpensive support (Serp et al., 2000; Gabardo et al., 2016).

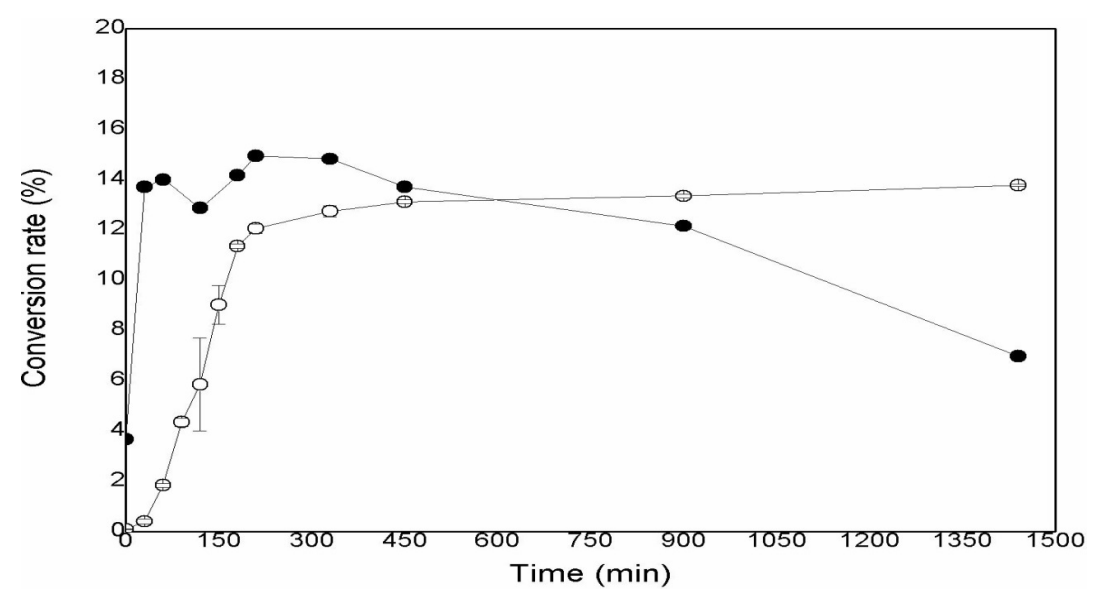

Figure 4. Conversion rate of lactose solution $\left(50 \mathrm{~g} \mathrm{~L}^{-1}\right)$ by free (-๑-) and immobilized enzyme (-०-) from enzyme solution of $2 \mathrm{U}$ at $37^{\circ} \mathrm{C}$. Results are the mean of duplicates.

\section{Conclusions}

The porungo cheese whey showed to be a promising substrate to produce $\beta$-galactosidase, as well as allowing added-value to this agro-industrial by-product, i.e., reducing environmental damage. The immobilization technique of the enzyme increased an optimal temperature range for the enzyme and provided the maintenance of the operational stability of the system in hydrolysis tests. The $\beta$-galactosidase produced by $K$. marxianus CCT 4086 demonstrated it biotechnological potential for reducing the amount of the lactose in solutions, such as the cheese whey. 


\section{References}

Alonso, N., López-Gallego, F., Betancor, L., Hidalgo, A., Mateo, C., Guisan, J. M., \& Fernandez-Lafuente, R. (2005). Immobilization and stabilization of glutaryl acylase on aminated sepabeads supports by the glutaraldehyde crosslinking method. Journal of Molecular Catalysis. B, Enzymatic, 35(1-3), 57-61. http://dx.doi.org/10.1016/j.molcatb.2005.05.007

Alves, F. G. (2008). Produção de $\beta$-galactosidade de Kluyveromyces marxianus CCT 7082 em fermentador e caracterização parcial da enzima livre e imobilizada (Dissertação de mestrado). Universidade Federal do Rio Grande, Rio Grande.

Amsden, B., \& Turner, N. (1999). Diffusion characteristics of calcium alginate gels. Biotechnology and Bioengineering, 65(5), 605-610. PMid:10516587. http://dx.doi.org/10.1002/(SICI)1097-0290(19991205)65:5<605::AID-BIT14>3.0.CO;2-C

Barbosa, O., Ortiz, C., Berenguer-Murcia, Á., Torres, R., Rodrigues, R. C., \& Fernandez-Lafuente, R. (2015). Strategies for the one-step immobilization-purification of enzymes as industrial biocatalysts. Biotechnology Advances, 33(5), 435-456. PMid:25777494. http://dx.doi.org/10.1016/j.biotechadv.2015.03.006

Betancor, L., López-Gallego, F., Hidalgo, A., Alonso-Morales, N., Mateo, G. D. O. C., Fernández-Lafuente, R., \& Guisán, J. M. (2006). Different mechanisms of protein immobilization on glutaraldehyde activated supports: Effect of support activation and immobilization conditions. Enzyme and Microbial Technology, 39(4), 877-882. http://dx.doi.org/10.1016/j.enzmictec.2006.01.014

Bolognesi, L. S., Gabardo, S., Dall Cortivo, P. R., \& Ayub, M. A. Z. (2021). Biotechnological production of galactooligosaccharides (GOS) using porungo cheese whey. Food Science and Technology, 41, 1-6. http://dx.doi.org/10.1590/fst.64520

Braga, A. R. C., Gomes, P. A., \& Kalil, S. J. (2012). Formulation of culture medium with agroindustrial waste for $\beta$-galactosidase production from Kluyveromyces marxianus ATCC 16045. Food and Bioprocess Technology, 5(5), 1653-1663. http://dx.doi.org/10.1007/s11947-011-0511-0

Fai, A. E. C., \& Pastore, G. M. (2015). Galactooligosacáridos: Producción, beneficios para la salud, aplicación en alimentos y perspectivas. Scientia Agropecuaria, 6(1), 69-81. http://dx.doi.org/10.1007/s11947-011-0511-0

Christensen, A. D., Kádár, Z., Oleskowicz-Popiel, P., \& Thomsen, M. H. (2011). Production of bioethanol from organic whey using Kluyveromyces marxianus. Journal of Industrial Microbiology \& Biotechnology, 38(2), 283-289. PMid:20632200. http://dx.doi.org/10.1007/s10295-010-0771-0

Coelho, R. J. S., Gabardo, S., Marim, A. V. C., Bolognesi, L. S., Pimentel Filho, N. J., \& Ayub, M. A. Z. (2021). Porungo cheese whey: A new substrate to produce $\beta$-galactosidase. Annals of the Brazilian Academy of Sciences. In press.

Das, M., Raychaudhuri, A., \& Ghosh, S. K. (2016). Supply chain of bioethanol production from whey: A review. Procedia Environmental Sciences, 35, 833-846. http://dx.doi.org/10.1016/j.proenv.2016.07.100

Davani-Davari, D., Negahdaripour, M., Karimzadeh, I., Seifan, M., Mohkam, M., Masoumi, S. J., Berenjian, A., \& Ghasemi, Y. (2019). Prebiotics: Definition, types, sources, mechanisms, and clinical applications. Foods, 8(3), 92. PMid:30857316. http://dx.doi.org/10.3390/foods8030092

Domingos, J. M., Puccio, S., Martinez, G. A., Amaral, N., Reis, M. A., Bandini, S., Fava, F., \& Bertin, L. (2018). Cheese whey integrated valorisation: Production, concentration and exploitation of carboxylic acids for the production of polyhydroxyalkanoates by a fed-batch culture. Chemical Engineering Journal, 336, 47-53. http://dx.doi.org/10.1016/j.cej.2017.11.024

Falleiros, L. N. S. S. (2016). Produção e caracterização de B-galactosidase de Kluyveromyces marxianus ATCC 46537 (Tese de doutorado). Universidade Federal de Uberlândia, Uberlândia.

Fan, J., Luo, J., \& Wan, Y. (2017). Membrane chromatography for fast enzyme purification, immobilization and catalysis: A renewable biocatalytic membrane. Journal of Membrane Science, 538, 68-76. http://dx.doi.org/10.1016/j.memsci.2017.05.053

Fischer, C., \& Kleinschmidt, T. (2015). Synthesis of galactooligosaccharides using sweet and acid whey as a substrate. International Dairy Journal, 48, 15-22. http://dx.doi.org/10.1016/j.idairyj.2015.01.003

Freitas, A. P. B. (2017). Estudo comparativo dos processos produtivos, propriedades e aplicações de beta-galactosidase obtida de diferentes fontes (Trabalho de conclusão de curso). Universidade Federal de Uberlândia, Uberlândia.

Gabardo, S., Rech, R., \& Ayub, M. A. Z. (2011). Determination of lactose and ethanol diffusion coefficients in calcium alginate gel spheres: Predicting values to be used in immobilized bioreactors. Journal of Chemical \& Engineering Data, 56(5), 23052309. http://dx.doi.org/10.1021/je101288g

Gabardo, S., Rech, R., Rosa, C. A., \& Ayub, M. A. Z. (2014). Dynamics of ethanol production from whey and whey permeate by immobilized strains of Kluyveromyces marxianus in batch and continuous bioreactors. Renewable Energy, 69, 89-96. http://dx.doi.org/10.1016/j.renene.2014.03.023

Gabardo, S., Pereira, G. F., Klein, M. P., Rech, R., Hertz, P. F., \& Ayub, M. A. Z. (2016). Dynamics of yeast immobilized-cell fluidized-bed bioreactors systems in ethanol fermentation from lactose-hydrolyzed whey and whey permeate. Bioprocess and Biosystems Engineering, 39(1), 141-150. PMid:26527573. http://dx.doi.org/10.1007/s00449-015-1498-0

Grosová, Z., Rosenberg, M., \& Rebroš, M. (2008). Perspectives and applications of immobilised $\beta$-galactosidase in food industry: A review. Czech Journal of Food Sciences, 26(1), 1-14. http://dx.doi.org/10.17221/1134-CJFS

Guimarães, P. M., Teixeira, J. A., \& Domingues, L. (2010). Fermentation of lactose to bio-ethanol by yeasts as part of integrated solutions for the valorisation of cheese whey. Biotechnology Advances, 28(3), 375-384. PMid:20153415.

http://dx.doi.org/10.1016/j.biotechadv.2010.02.002 
Haider, T., \& Husain, Q. (2009). Hydrolysis of milk/whey lactose by $\beta$ galactosidase: A comparative study of stirred batch process and packed bed reactor prepared with calcium alginate entrapped enzyme. Chemical Engineering and Processing: Process Intensification, 48(1), 576-580. http://dx.doi.org/10.1016/j.cep.2008.02.007

Husain, Q. (2010). $\beta$ Galactosidases and their potential applications: A review. Critical Reviews in Biotechnology, 30(1), 41-62. PMid:20143935. http://dx.doi.org/10.3109/07388550903330497

Illanes, A., Altamirano, C., Aillapán, A., Tomasello, G., \& Zuniga, M. E. (1998). Packed-bed reactor performance with immobilized lactase under thermal inactivation. Enzyme and Microbial Technology, 23(1-2), 3-9. http://dx.doi.org/10.1016/S0141-0229(98)00027-1

Jochems, P., Satyawali, Y., Van Roy, S., Doyen, W., Diels, L., \& Dejonghe, W. (2011). Characterization and optimization of $\beta$ galactosidase immobilization process on a mixed-matrix membrane. Enzyme and Microbial Technology, 49(6-7), 580-588. PMid:22142735. http://dx.doi.org/10.1016/j.enzmictec.2011.06.010

Klein, M. P., Fallavena, L. P., Schöffer, J. D. N., Ayub, M. A., Rodrigues, R. C., Ninow, J. L., \& Hertz, P. F. (2013). High stability of immobilized $\beta$-d-galactosidase for lactose hydrolysis and galactooligosaccharides synthesis. Carbohydrate Polymers, 95(1), 465-470. PMid:23618294. http://dx.doi.org/10.1016/j.carbpol.2013.02.044

Krajewska, B. (2004). Application of chitin-and chitosan-based materials for enzyme immobilizations: A review. Enzyme and Microbial Technology, 35(2-3), 126-139. http://dx.doi.org/10.1016/j.enzmictec.2003.12.013

Lane, M. M., Burke, N., Karreman, R., Wolfe, K. H., O’Byrne, C. P., \& Morrissey, J. P. (2011). Physiological and metabolic diversity in the yeast Kluyveromyces marxianus. Antonie van Leeuwenhoek, 100(4), 507-519. PMid:21674230. http://dx.doi.org/10.1007/s10482-011-9606-x

Medeiros, F. O. D., Alves, F. G., Lisboa, C. R., Martins, D. D. S., Burkert, C. A. V., \& Kalil, S. J. (2008). Ondas ultrassônicas e pérolas de vidro: Um novo método de extração de beta-galactosidase para uso em laboratório. Quimica Nova, 31(2), 336-339. http://dx.doi.org/10.1590/S0100-40422008000200028

Miller, G. L. (1959). Use of dinitrosalicylic acid reagent for determination of reducing sugar. Analytical Chemistry, 31(3), 426428. http://dx.doi.org/10.1021/ac60147a030

Mörschbächer, A. P., Volpato, G., \& Souza, C. F. V. D. (2016). Kluyveromyces lactis $\beta$-galactosidase immobilization in calcium alginate spheres and gelatin for hydrolysis of cheese whey lactose. Ciência Rural, 46(5), 921-926. http://dx.doi.org/10.1590/0103-8478cr20150833

Numanoğlu, Y., \& Sungur, S. (2004). $\beta$-Galactosidase from Kluyveromyces lactis cell disruption and enzyme immobilization using a cellulose-gelatin carrier system. Process Biochemistry, 39(6), 705-711. http://dx.doi.org/10.1016/S0032-9592(03)001833

Panesar, P. S., Kumari, S., \& Panesar, R. (2010). Potential applications of immobilized $\beta$-galactosidase in food processing industries. Enzyme Research, 2010, 473137. PMid:21234407. http://dx.doi.org/10.4061/2010/473137

Park, A. R., \& Oh, D. K. (2010). Galacto-oligosaccharide production using microbial $\beta$-galactosidase: Current state and perspectives. Applied Microbiology and Biotechnology, 85(5), 1279-1286. PMid:19943044. http://dx.doi.org/10.1007/s00253009-2356-2

Pereira, M. C. S., Brumano, L. P., Kamiyama, C. M., Pereira, J. P. F., Rodarte, M. P., \& Pinto, M. A. O. (2012). Lácteos com baixo teor de lactose: Uma necessidade para portadores de má digestão da lactose e um nicho de mercado. Revista do Instituto de Latícinios Cândido Tostes, 67(389), 57-65. http://dx.doi.org/10.5935/2238-6416.20120079

Pezzo, M. (2017). Porungo: Queijo tradicional da Região do Campus Lagoa do Sino está no centro de parceria entre pesquisadores e produtores locais. Revista da Universidade Federal de São Carlos, 4(2), 36-42. Retrieved in 2021, February 26, from http://revista.ufscar.br/edicoes-online/02/files/basic-html/page36.html

Pilkington, P. H., Margaritis, A., Mensour, N. A., \& Russell, I. (1998). Fundamentals of immobilised yeast cells for continuous beer fermentation: A review. Journal of the Institute of Brewing, 104(1), 19-31. http://dx.doi.org/10.1002/j.20500416.1998.tb00970.x

Prazeres, A. R., Carvalho, F., \& Rivas, J. (2012). Cheese whey management: A review. Journal of Environmental Management, 110, 48-68. PMid:22721610. http://dx.doi.org/10.1016/j.jenvman.2012.05.018

Rech, R., Cassini, C. F., Secchi, A., \& Ayub, M. A. Z. (1999). Utilization of protein-hydrolyzed cheese whey for production of $\beta$ galactosidase by Kluyveromyces marxianus. Journal of Industrial Microbiology \& Biotechnology, 23(2), 91-96. PMid:10510485. http://dx.doi.org/10.1038/sj.jim.2900692

Rosenberg, Z. M. M. (2006). Current trends of $\beta$-galactosidase application in food technology. Journal of Food and Nutrition Research, 45(2), 47-54.

Rubio-Texeira, M. (2006). Endless versatility in the biotechnological applications of Kluyveromyces LAC genes. Biotechnology Advances, 24(2), 212-225. PMid:16289464. http://dx.doi.org/10.1016/j.biotechadv.2005.10.001

Santiago, P. A., Marquez, L. D., Cardoso, V. L., \& Ribeiro, E. J. (2004). Estudo da produção de beta-galactosidase por fermentação de soro de queijo com Kluyveromyces marxianus. Food Science and Technology, 24(4), 567-572. http://dx.doi.org/10.1590/S0101-20612004000400015

Serp, D., Cantana, E., Heinzen, C., Von Stockar, U., \& Marison, I. W. (2000). Characterization of an encapsulation device for the production of monodisperse alginate beads for cell immobilization. Biotechnology and Bioengineering, 70(1), 41-53. PMid:10940862. http://dx.doi.org/10.1002/1097-0290(20001005)70:1<41::AID-BIT6>3.0.CO;2-U

Sheldon, R. A., \& Van Pelt, S. (2013). Enzyme immobilisation in biocatalysis: Why, what and how. Chemical Society Reviews, 42(15), 6223-6235. PMid:23532151. http://dx.doi.org/10.1039/C3CS60075K 
Siso, M. G. (1996). The biotechnological utilization of cheese whey: A review. Bioresource Technology, 57(1), 1-11. http://dx.doi.org/10.1016/0960-8524(96)00036-3

Song, Y. S., Lee, J. H., Kang, S. W., \& Kim, S. W. (2010). Performance of $\beta$-galactosidase pretreated with lactose to prevent activity loss during the enzyme immobilisation process. Food Chemistry, 123(1), 1-5. http://dx.doi.org/10.1016/j.foodchem.2010.04.043

Zhang, Z., Zhang, F., Song, L., Sun, N., Guan, W., Liu, B., Tian, J., Zhang, Y., \& Zhang, W. (2018). Site-directed mutation of $\beta$ galactosidase from Aspergillus candidus to reduce galactose inhibition in lactose hydrolysis. 3 Biotech, 8(11), 452. PMid:30333954. http://dx.doi.org/10.1007/s13205-018-1418-5

Zhao, L., Zhou, Y., Qin, S., Qin, P., Chu, J., \& He, B. (2018). $\beta$-Galactosidase BMG without galactose and glucose inhibition: Secretory expression in Bacillus subtilis and for synthesis of oligosaccharide. International Journal of Biological Macromolecules, 120(Pt A), 274-278. PMid:30055277. http://dx.doi.org/10.1016/j.ijbiomac.2018.07.148

Zhou, Q. Z., \& Chen, X. D. (2001). Effects of temperature and pH on the catalytic activity of the immobilized $\beta$-galactosidase from Kluyveromyces lactis. Biochemical Engineering Journal, 9(1), 33-40. http://dx.doi.org/10.1016/S1369-703X(01)00118-8

Funding: None. 